\title{
ANALISIS PENERAPAN AKUNTANSI BERBASIS AKRUAL DALAM PENYAJIAN LAPORAN KEUANGAN PADA BADAN PENGELOLA KEUANGAN DAN ASET DAERAH PROVINSI SULAWESI UTARA
}

\author{
Anastasya A. Lasabuda ${ }^{1}$, Jenny Morasa ${ }^{2}$, Victorina Z. Tirayoh ${ }^{3}$ \\ 1,2,3 Jurusan Akuntansi, Fakultas Ekonomi dan Bisnis, Universitas Sam Ratulangi, Jl. Kampus \\ Unsrat, Manado, Indonesia, 95115
}

E-mail: anastasyalasabuda19@gmail.com

\begin{abstract}
All government entities using funds from national and regional budgets must prepare financial reports referring to government accounting standards which regulated in government regulation No 71 in 2010 and start begin on 2015. The regional goverment financial reports required to be properly according to applicable regulation. Financial reports regional was a responsibility and performance picture in an accounting periods. The purpose of this study was to analyze the accrual basis implementation of SAP No 71 years 2010 and to know the impact ot the financial statement presentation on BPKAD in North Sulawesi Province. Methods used is descriptive qualitative, through observation, interview, analysis and make inferences. The research results showed the application of the base accrued in BPKAD of North Sulawesi Province in the presentation of the financial statements was in accordance with SAP No 71 years 2010. The impact caused by the accounting system based accrual that this report financial more than easier, quick and integrated, and can tell about information budget expended and can be monitored directly by the management to decision maker.

Keywords: accrual base; financial statement; government accounting; standard accounting system
\end{abstract}

\section{PENDAHULUAN}

Pemerintah berperan dalam meningkatkan informasi keuangan dalam pengelolaan keuangan, untuk itu perlu melakukan reformasi dalam hal penyajian laporan keuangan dalam dasar yang kuat sebagai acuan (Tumbel et al., 2019; Rombebunga et al., 2013). Komite Standar Akuntansi Pemerintahan (KSAP) telah menyusun Standar Akuntansi Pemerintahan (SAP) sebagai panduan atas laporan keuangan berbasis akrual yang ditetapkan dengan Peraturan Pemerintah Nomor 71 tahun 2010 menggantikan Peraturan Pemerintah Nomor 24 tahun 2005. Ditetapkannya Peraturan Pemerintah Nomor 71 tahun 2010 maka penerapan standar akuntansi pemerintahan berbasis akrual telah mempunyai landasan hukum. Hal ini juga berarti bahwa pemerintah mempunyai kewajiban untuk dapat segera menerapkan SAP yang baru yaitu SAP berbasis akrual. Berlakunya Peraturan Pemerintah Nomor 71 tahun 2010 tentang SAP berbasis akrual membawa perubahan besar dalam sistem pelaporan keuangan di Indonesia, yaitu perubahan dari basis kas menuju akrual menjadi basis akrual penuh dalam pengakuan transaksi keuangan pemerintah. Perubahan basis tersebut selain telah diamanatkan oleh paket Undang-Undang Keuangan Negara, juga diharapkan mampu memberikan gambaran yang utuh atas posisi keuangan, menyajikan informasi yang sebenarnya mengenai hak dan kewajiban dan bermanfaat dalam mengevaluasi kinerja.

Pemerintah Provinsi Sulawesi Utara dalam membiayai kegiatan dan pelaksanaan tugasnya memperoleh alokasi dana dari Anggaran Pendapatan dan Belanja Daerah (APBD). 
Oleh karena itu, Pemerintah Sulawesi Utara wajib menyusun laporan keuangan sebagai bentuk pertanggungjawaban atas pengelolaan anggaran daerah yang diperolehnya. Pemerintah Provinsi Sulawesi Utara wajib menyusun laporan keuangan yang berlandaskan pada SAP yang berlaku. Kesesuaian penyajian laporan keuangan dengan standar akuntansi pemerintahan menjadi dasar diberikannya opini atas laporan keuangan pemerintah Provinsi Sulawesi Utara. Pemerintah Sulawesi Utara sendiri, pada tahun 2015 telah menerapkan akuntansi berbasis akrual.

\section{TINJAUAN PUSTAKA}

Menurut Sujarweni (2014:18), akuntansi pemerintahan adalah akuntansi yang bersangkutan dengan bidang keuangan negara dari anggaran sampai pelaksanaan dan pelaporan termasuk pengaruh yang ditimbulkan. Menurut Mahsun (2006), laporan keuangan pemerintah daerah adalah hasil dari proses akuntansi keuangan pemerintah daerah yang berisi Neraca, Laporan Realisasi Anggaran, Laporan Arus Kas, dan Catatan atas Laporan Keuangan, untuk digunakan oleh pihak-pihak eksternal yang berkepentingan. Setelah Undang-Undang Nomor 1 Tahun 2004 ditetapkan, selanjutnya ditetapkan Undang-Undang Republik Indonesia Nomor 32 Tahun 2004 tentang Pemerintahan Daerah pada pasal 184 ayat (1) dan (2) yang menyatakan bahwa laporan keuangan pemerintah disusun dan disajikan sesuai dengan SAP yang ditetapkan dengan Peraturan Pemerintah, dan dilanjutkan dengan ditetapkan Undang-Undang Nomor 33 Tahun 2004 tentang perimbangan keuangan antara pemerintahan pusat dan daerah. Setelah kurang lebih lima tahun berlalu, pemerintah melalui KSAP pada tanggal 22 Oktober 2010 mengeluarkan Peraturan Pemerintah Nomor 71 Tahun 2010 tentang Standar Akuntansi Pemerintahan.

Permendagri Nomor 64 tahun 2013 memuat prinsip-prinsip akuntansi yang diterapkan dalam menyusun dan menyajikan laporan keuangan pemerintah. SAP merupakan persyaratan yang mempunyai kekuatan hukum dalam upaya meningkatkan kualitas laporan keuangan di Indonesia. Menurut Darise (2008:38), basis akuntansi merupakan prinsip-prinsip akuntansi yang menentukan kapan pengaruh atas transaksi atau kejadian harus diakui untuk tujuan pelaporan keuangan. Basis akuntansi ini berhubungan dengan waktu kapan pengukuran dilakukan. Basis akuntansi pada umumnya ada dua yaitu basis kas dan basis akrual. Terdapat modifikasi dari keduanya, yaitu basis kas dan basis akrual sama-sama digunakan dalam menyajikan laporan keuangan.

Menurut Halim dan Kusyufi (2014:49), basis akuntansi akrual seperti yang telah disimpulkan adalah akuntansi yang mengakui transaksi dan peristiwa lainnya pada saat transaksi dan peristiwa tersebut terjadi (bukan hanya pada saat kas yang dterima atau dibayar). Langelo et al. (2015) menunjukkan bahwa pemerintah kota Bitung belum menerapkan PP No.71 Tahun 2010 tetapi telah sesuai dengan PP Nomor 24 Tahun 2005 yaitu menggunakan basis kas menuju akrual. Surepno (2015) menunjukkan bahwa keberhasilan implementasi akuntansi berbasis akrual Pemerintah Kota Semarang didukung oleh empat strategi utama yaitu komitmen pimpinan, pengembangan regulasi, pengembangan sistem informasi dan pengembangan sumber daya manusia. Sukamdaru et al. (2017) menunjukkan bahwa pelatihan dan pengalaman kerja berpengaruh positif terhadap pemahaman laporan keuangan berbasis akrual. Lamonisi (2016) menunjukkan bahwa Pemerintah Kota Tomohon dalam menerapkan SAP berbasis akrual telah melaksanakan berbagai pelatihan-pelatihan.

\section{METODE PENELITIAN}

Metode yang digunakan dalam penelitian ini adalah metode deskriptif, yaitu metode untuk menguraikan suatu keadaan nyata yang ditemukan, kemudian menganalisis data yang ada hubungannya dengan pencatatan dan penilaian persediaan. Proses analisis data yang berkaitan dengan akuntansi berbasis akrual dalam penyajian laporan keuangan adalah: 
1. Tahap pertama. Dimulai dengan mengumpulkan data dari pegawai Badan Pengelola Keuangan dan Aset Daerah (BPKAD) Provinsi Sulawesi Utara, dimana data tersebut berupa hasil wawancara, data keuangan, dan dokumen lainnya berupa sejarah perusahaan, visi misi perusahaan dan lainnya.

2. Tahap kedua. Melakukan analisis atas hasil wawancara dan menarik kesimpulan atas kesesuaian penyajian laporan keuangan serta penerapan basis akrual pada Badan Pengelola Keuangan dan Aset Daerah (BPKAD) Provinsi Sulawesi Utara. Langkah berikutnya menganalisis dampak yang diperoleh atas berlakunya SAP nomor 71 Tahun 2010 terhadap informasi yang disajikan dalam laporan keuangan dengan membandingkan antara sebelum dan sesudah penerapan tersebut yang telah diterapkan pada tahun 2015.

\section{HASIL PENELITIAN DAN PEMBAHASAN}

\subsection{Hasil penelitian}

Prosedur keuangan daerah BPKAD Provinsi Sulawesi Utara dimulai pada saat Anggaran Pendapatan dan Belanja Daerah (APBD) disahkan oleh DPRD. Berdasarkan APBD yang disahkan oleh Sub Bagian Anggaran membuat Surat Ketetapan Otorisasi (SKO) sebagai dasar pemerintah dan pengajuan Surat Permintaan Pembayaran (SPP) oleh satuan kerja yang ada di lingkungan Pemerintah Provinsi Sulawesi Utara. SPP yang diajukan oleh setiap satuan kerja akan diverifikasi oleh Sub Bagian Verifikasi dan Sub Bagian Anggaran.

Pemerintah Provinsi Sulawesi Utara dalam pelaporan keuangan Daerah berpedoman pada Permendagri Nomor 13 tahun 2006 dengan melaksanakan tata usaha keuangan daerah dengan pedoman Sistem dan Prosedur Penatausahaan dan Akuntansi, Pelaporan, dan Pertanggungjawaban keuangan daerah yang terdiri dari Laporan Arus kas, Laporan Realisasi/Perhitungan APBD, Neraca dan perhitungan anggaran. Hasil wawancara dan pengamatan dari penelitian ini adalah:

1. Persiapan basis akrual.

a. Diterbitkannya peraturan Gubernur Sulawesi Utara Nomor 10 tahun 2014 tentang kebijakan akuntansi sebagai acuan penyusunan laporan keuangan bagi entitas akuntansi dan entitas pelaporan di pemerintah daerah Provinsi Sulawesi Utara.

b. Perubahan sistem akuntansi yang digunakan dalam pencatatan akuntansi yaitu Sistem Informasi Manajemen Perencanaan dan Pelaporan (SIMRAL) tahun 2015 dari sebelumnya menggunakan Sistem Informasi Akuntansi Keuangan (SIAKU).

c. Pendidikan dan pelatihan untuk SDM yang berkaitan dengan pelaporan dilakukan untuk petugas akuntansi selaku yang menyusuan laporan keuangan dan aset tetap yang mengelola barang milik daerah.

\section{Basis akrual.}

a. Pengakuan pendapatan LO dan beban dalam laporan operasional.

b. Pengakuan ekuitas dalam neraca yang berasal dari laporan perubahan ekuitas.

c. Pengakuan surplus/defisit LO dalam laporan perubahan ekuitas.

d. Laporan realisasi anggaran menyajikan anggaran dengan realisasi belanja.

e. Penjelasan pos-pos dan akun-akun dalam laporan keuangan secara rinci.

3. Penyusunan laporan keuangan. Proses penyusunan laporan keuangan Pemerintah Provinsi Sulawesi Utara dilakukan secara bertahap. Setiap 3 bulan sekali, masing-masing Satuan Kerja Perangkat Daerah (SKPD) melakukan rekonsiliasi dengan BPKAD Provinsi Sulawesi Utara. Rekonsiliasi laporan keuangan yang dilakukan meliputi Laporan Realisasi Anggraran (LRA), Laporan Operasional (LO), Laporan Perubahan Ekuitas (LPE), Neraca dan Catatan atas Laporan Keuangan (CaLK).

4. Laporan keuangan. Proses penyajian laporan keuangan, berbasis web menggunakan aplikasi $e$-Accounting untuk akuntansi, $e$-inventory untuk persediaan, e-Simba dan untuk barang. Penyajian laporan keuangan di e-Accounting adalah berbasis akrual. 


\begin{tabular}{lllll} 
Tabel 1. Hasil analisis perbedaan pada BPKAD Provinsi Sulawesi Utara dan PP 71 tahun 2010 \\
\hline $\begin{array}{l}\text { No } \\
\text { Basis akrual } \\
\text { penyajian } \\
\text { keuangan }\end{array}$ & $\begin{array}{c}\text { dalam } \\
\text { laporan }\end{array}$ & $\begin{array}{l}\text { BPKAD Provinsi } \\
\text { Utara }\end{array}$ & Sulawesi & PP 71 Tahun 2010 \\
\hline 1. & Pendapatan-LO & Tidak terdapat pendapatan-LO & Berasal dari kegiatan \\
& yang disajikan dalam laporan operasional yaitu pendapatan \\
& keuangan Provinsi Sulut baik asli daerah LO, pendapatan \\
pendapatan PAD-LO, transfer-LO & transfer LO dan pendapatan \\
dan pendapatan lain-lain-LO. & $\begin{array}{l}\text { lain lain-LO berasal dari } \\
\text { pajak dan retribusi, dana }\end{array}$ \\
& & $\begin{array}{l}\text { alokasi khusus dan hibah dari } \\
\text { pemerintah kota maupun }\end{array}$ \\
& & provinsi.
\end{tabular}

2. Neraca

3. Ekuitas awal

4. Laporan Anggaran

5. Neraca

6. Laporan perubahan ekuitas
Posisi keuangan entitas terdiri dari aset lancar, aset tetap, aset tak berwujud dan ekuitas

Berasal dari saldo akhir ekuitas periode tahun sebelumnya

Realisasi

Nilai yang disajikan hanya berupa pada anggaran dan belanja. Tidak terdapat transfer dan pembiayaan.

Meliputi pos kas di bendahara pengeluaran, persediaan, aset tetap, aset tak berwujud dan ekuitas.

Belum menjelaskan akun-akun dalam laporan perubahan ekuitas pada CALK.
Menjelaskan posisi keuangan yang meliputi aset, kewajiban dan ekuitas secara lengkap.

Berasal dari saldo akhir ekuitas periode tahun sebelumnya.

Menyajikan pendapatan, pada anggaran dan belanja, transfer dan pembiayaan.

Menjelaskan secara rinci pos-pos dalam laporan posisi keuangan (neraca) dibandingkan tahun sebelumnya.

Menjelaskan lengkap pos-pos ekuitas awal, surplus/ defisit, koreksi dan ekuitas akhir yang diperoleh.

Sumber: Data BPKAD, 2017

Pada basis akrual dalam penyajian laporan keuangan pada Pendapatan-LO di BPKAD Provinsi Sulawesi Utara tidak terdapat sedangkan di PP 71 tahun 2010 terdapat yang berasal dari kegiatan operasional, untuk Neraca dan Ekuitas awal pada BPKAD Provinsi Sulawesi Utara dan PP 71 Tahun 2010 telah sesuai, untuk Laporan Realisasi Anggaran pada BPKAD Provinsi Sulawesi Utara tidak terdapat transfer dan pembiayaan sedangkan di PP 71 Tahun 2010 terdapat transfer dan pembiayaan, untuk Neraca di BPKAD Provinsi Sulawesi Utara pos kas di bendahara pengeluaran, persediaan, aset tetap, aset tak berwujud dan Ekuitas sedangkan di PP 71 Tahun 2010 menjelaskan secara rinci pos-pos dalam laporan posisi keuangan (neraca) dibandingkan tahun sebelumnya, dan untuk Laporan Perubahan Ekuitas pada BPKAD Provinsi Sulawesi Utara belum menjelaskan akun-akun dalam laporan perubahan ekuitas pada CALK sedangkan pada PP 71 Tahun 2010 menjelaskan lengkap pospos ekuitas awal, surplus/ defisit, koreksi dan ekuitas akhir yang diperoleh. 
Tabel 2. Dampak yang ditimbulkan

\begin{tabular}{|c|c|c|c|}
\hline \multirow[t]{2}{*}{ No. } & \multirow[t]{2}{*}{ Uraian } & \multicolumn{2}{|c|}{ Hasil penerapan akrual } \\
\hline & & Sebelum 2015 & Setelah 2015 \\
\hline 1. & Persiapan akrual basis. & $\begin{array}{l}\text { Peraturan Gubernur tentang } \\
\text { kebijakan akuntansi basis kas } \\
\text { menuju akrual. }\end{array}$ & $\begin{array}{l}\text { Adanya peraturan Gubernur } \\
\text { tentang kebijakan akuntansi } \\
\text { pemerintah daerah dan } \\
\text { sistem akuntansi pemerintah } \\
\text { daerah tentang basis akrual }\end{array}$ \\
\hline 2. & $\begin{array}{l}\text { Pengakuan dan } \\
\text { pengukuran penyusutan } \\
\text { aset tetap. }\end{array}$ & $\begin{array}{l}\text { Belum dilakukan penyusutan } \\
\text { aset tetap terhadap akun } \\
\text { belanja modal SKPD. }\end{array}$ & $\begin{array}{l}\text { Penyusutan aset tetap } \\
\text { dilakukan terhadap belanja } \\
\text { modal yang dibeli oleh } \\
\text { SKPD mulai tahun } 2015\end{array}$ \\
\hline 3. & $\begin{array}{l}\text { Pengakuan } \\
\text { pengukuran } \\
\text { beban dan } \\
\text { pendapatan - } \\
\text { LO yang timbul. }\end{array}$ & $\begin{array}{l}\text { Belum mengukur } \\
\text { mengakui dan } \\
\text { pendapatan-LO. }\end{array}$ & $\begin{array}{lcr}\text { Mulai } & \text { disajikan } & \text { dalam } \\
\text { laporan } & \text { keuangan } & \text { yaitu } \\
\text { laporan } & \text { operasional } & \text { tahun } \\
\text { 2015. } & & \end{array}$ \\
\hline 4. & $\begin{array}{l}\text { Perubahan } \\
\text { pengungkapan dalam } \\
\text { CALK. }\end{array}$ & $\begin{array}{l}\text { Sesuai SAP basis kas menuju } \\
\text { akrual. }\end{array}$ & $\begin{array}{l}\text { Semua informasi dan akun- } \\
\text { akun dalam laporan } \\
\text { keuangan diungkapkan } \\
\text { secara memadai } \\
\text { disclousure) sesuai } \\
\text { basis akrual. }\end{array}$ \\
\hline 5. & $\begin{array}{l}\text { Laporan keuangan yang } \\
\text { dihasilkan. }\end{array}$ & $\begin{array}{l}\text { Laporan realisasi anggaran, } \\
\text { neraca dan CALK. }\end{array}$ & $\begin{array}{l}\text { Laporan realisasi anggaran, } \\
\text { neraca, laporan operasional, } \\
\text { laporan perubahan ekuitas } \\
\text { dan CALK. }\end{array}$ \\
\hline 6. & $\begin{array}{l}\text { Dampak } \\
\text { ditimbulkan. }\end{array}$ & $\begin{array}{l}\text { Sistem akuntansi belum } \\
\text { terintegrasi secara langsung, } \\
\text { Sehingga dimungkinkan } \\
\text { adanya penginputan yang } \\
\text { dilakukan oleh petugas aset } \\
\text { dan juga petugas akuntansi } \\
\text { pelaporan. }\end{array}$ & $\begin{array}{l}\text { Sitem akuntansi lebih } \\
\text { terintegrasi sehingga } \\
\text { memudahkan penginputan } \\
\text { belanja modal oleh } \\
\text { petugas aset dalam } \\
\text { menyusun laporan keuangan. }\end{array}$ \\
\hline
\end{tabular}

Sumber: Data olah, 2017

Tabel 2 menunjukkan bahwa BPKAD Provinsi Sulawesi Utara sudah siap dalam penerapan standar akuntansi pemerintah berbasis akrual dalam penyajian laporan keuangan. Kehadiran standar akuntansi pemerintah berbasis akrual dinilai sedikit menyulitkan hal tersebut berangkat dari kendala yang dihadapi yaitu, sistem informasi, sumber daya manusia, strategi dasar yang dapat dipergunakan untuk penerapan standar akuntansi pemerintah berbasis akrual yaitu dengan mengandalkan SDM yang memahami regulasi di bidang keuangan daerah dan akuntansi. Dimana pengelolaan sumber daya manusia berarti penyiapan dan pelaksanaan suatu rencana yang terkoordinasi untuk menjamin bahwa sumber daya manusia yang ada dapat dimanfaatkan dengan sebaik-baiknya untuk mencapai tujuan organisasi tersebut. Sistem infrastruktur merupakan pendukung utama fungsi-fungsi sistem sosial dan ekonomi dalam kehidupan sehari-hari masyarakat. Sistem infrastruktur dapat didefinisikan sebagai fasilitas-fasilitas atau struktur-struktur dasar, peralatan-peralatan, instalasi-instalasi yang dibangun dan yang dibutuhkan untuk berfungsinya sistem sosial dan sistem ekonomi masyarakat.

Peraturan pemerintah Nomor 71 tahun 2010 tentang Standar Akuntansi Pemerintahan yang berbasis kas berbuah menjadi standar akuntansi pemerintah berbasis akrual secara penuh mulai tahun 2015. Sebagaimana disebutkan dalam peraturan pemerintah Nomor 71 
tahun 2010 pasal 1 ayat (8) bahwa yang dimaksud dengan SAP berbasis akrual adalah standar akuntansi pemerintahan yang mengakui pendapatan, beban, aset, utang, dan ekuitas dalam pelaporan finansial berbasis akrual, serta mengakui pendapatan, belanja, dan pembiayaan dalam pelaporan pelaksanaan anggaran berdasarkan basis yang ditetapkan dalam APBN atau APBD.

Penjelasan di atas terhadap pengertian basis akrual, dapat dikatakan bahwa Pemerintah Provinsi Sulawesi Utara telah mengetahui akuntansi pemerintahan basis akrual itu seperti apa. Hal ini di perkuat juga dengan pemaparan yang diuraikan oleh Bapak Steven Kumenit selaku Kepala Sub Bidang Pelaporan Keuangan BPKAD Provinsi Sulawesi Utara. Bapak Steven mengatakan bahwa akuntansi berbasis akrual itu kita langsung mengakui pendapatan pada saat APBD ditetapkan. Jadi pada saat APBD ditetapkan kita sudah akui. Saat ditanyakan mengenai kendala terhadap penerapan peraturan ini, Bapak Steven Kumenit mengatakan bahwa:

1. Masih perlu adanya penyesuaian dalam hal penganggaran;

2. Pegawai harus memahami dalam penyusunan laporan keuangan karena ada ketambahan 3 laporan yaitu laporan perubahan SAL, LO dan laporan perubahan ekuitas;

3. Masalah regulasi di daerah dan juga sumber daya manusia-nya (SDM); dan

4. Hal yang masih perlu dilakukan oleh pemerintah terkait adanya peraturan ini antara lain: (a) masih perlu dilakukan sosialisasi dan bimbingan teknis; (b) mengikut sertakan pegawai-pegawai dalam sosialisasi dan bimbingan teknis yang diselenggarakan oleh departemen keuangan; (c) mengharuskan pegawai membaca dan memahami peraturan ini; dan (d) melaksanakan kursus dan pelatihan terkait hal ini.

\subsection{Pembahasan}

Penerapan akuntansi berbasis akrual pada penyajian laporan keuangan. Proses penyajian laporan keuangan, Badan Pengelola Keuangan dan Aset Daerah (BPKAD) Provinsi Sulawesi Utara telah menggunakan basis web, menggunakan aplikasi e-accounting untuk akuntansi, e-inventory untuk persediaan, e-simbada untuk barang. Penyajian laporan keuangan di e-accounting basis akrual. Basis akrual, mengandalkan skill akuntansi. Disini subbid akuntansi, mensupervisi, mendampingi, membimbing, untuk penjurnalan dari Laporan Operasional. Laporan Operasional, Laporan Perubahan Ekuitas, dan Neraca menggunakan accrual basis, sedangkan Laporan Realiasi Anggaran dan Laporan Perubahan Saldo Anggaran Lebih menggunakan cash basis. Penyajian laporan keuangan Provinsi Sulawesi Utara yang berbasis accrual, memerlukan banyak pelatihan maupun sosialisasi kepada semua Satuan Kerja Perangkat Daerah (SKPD) yang berada di bawah lingkup Pemerintahan Provinsi Sulawesi Utara. Ada berbagai SKPD dengan karateristik yang berbeda-beda, sehingga Pemerintah Provinsi Sulawesi Utara menerapkan treatment khusus untuk masingmasing SKPD dalam menunjang proses penyajian laporan keuangan Pemprov. Laporan keuangan tahunan Pemerintah Provinsi Sulawesi Utara, harus diserahkan tepat waktu kepada Badan Pemeriksa Keuangan (BPK), tetapi ada saja kendala dari SKPD dalam penyerahannya ke Pemprov, terutama kemampuan sumber daya manusia yang mengerjakan proses tersebut, meskipun Pemprov telah mengadakan pelatihan/sosialisasi maupun proses pendampingan dan koreksi secara intens kepada masing-masing SKPD.

Dampak yang terjadi atas penerapan basis akrual dalam penyusunan laporan keuangan meliputi:

1. Penyajian ekuitas akhir diperoleh dari laporan perubahan ekuitas sehingga dapat ditelusur perolehannya.

2. Perhitungan penyusutan dan amortisasi dapat dilakukan pada setiap pembelian untuk aset tetap dan aset tak berwujud dengan melihat harga perolehan dan masa manfaat sesuai kebijakan akuntansi yang berlaku. 
3. Adanya perubahan sistem akuntansi pemerintah daerah yaitu SIMRAL maka penyusunan laporan keuangan menjadi lebih mudah, terkoordinasi dan lebih terintegrasi mulai dari penginputan, pencatatan dan pelaporan.

4. Petugas SIAP BMD dan petugas akuntansi pelaporan dapat mengakses SIMRAL tersebut secara online, sehingga waktu pengerjaanya lebih fleksibel dan tidak hanya terbatas dikantor SKPD saja.

5. Adanya penerapan basis akrual yang didukung perubahan sistem akuntansi yang digunakan maka dapat memotivasi sumber daya manusia SKPD yang ada untuk update dan lebih terpacu dalam belajar informasi tehnologi (IT).

6. Sistem akuntansi pemerintah yang ada yaitu Sistem Informasi Manajemen Perencanaan, Penganggaran dan Pelaporan (SIMRAL) dapat digunakan oleh manajemen SKPD sampai dengan Gubernur setempat untuk memantau serapan anggaran tiap periode secara langsung (online) dan update, sehingga dapat membantu dalam pengambilan keputusan dan menentukan kebijakan-kebijakan baru untuk periode selanjutnya.

\section{KESIMPULAN DAN SARAN}

\subsection{Kesimpulan}

BPKAD Pemerintah Provinsi Sulawesi Utara dalam penerapan SAP Basis Akrual dalam penyajian laporan keuangan telah sesuai dengan Peraturan Pemerintah Nomor 71 Tahun 2010, walaupun masih $80 \%$ dengan kendala berupa sistem informasi, SDM yang kurang memadai, kurangnya tenaga ahli akuntansi dan aplikasi untuk menunjang sistem tersebut terkadang mengalami kendala (error). BPKAD dalam proses penerapan dan penyajian laporan keuangan, menggunakan basis web, mempunyai aplikasi e-accounting untuk akuntansi, e-inventory untuk persediaan, e-simbada untuk barang. Penyajian laporan keuangan di e-accounting basis akrual, otomatis mengandalkan keahlian akuntansi. Adanya PP No 71 tahun 2010 tentang akuntansi berbasis akrual maka laporan keuangan dari sebelumnya hanya 4 yaitu Laporan Realisasi Anggaran (LRA), Neraca, Laporan Arus Kas dan Catatan atas Laporan Keuangan (CaLK). Kini bertambah 3 Laporan keuangan yaitu Laporan Perubahan Saldo Anggaran Lebih, Laporan Operasional (LO), dan Laporan Perubahan Ekuitas.

Penerapan PP Nomor 71 Tahun 2010 tentang Akuntansi Berbasis Akrual atas penyajian laporan keuangan mempunyai perubahan yang signifikan terkait dampak positif. Beberapa dampak yang timbul antara lain adalah penyajian ekuitas akhir diperoleh dari laporan perubahan penyusutan/amortisasi dapat dilakukan pada setiap pembelian untuk aset tetap dan aset tak berwujud, memudahkan penyusunan laporan keuangan dengan sistem yang lebih terintegrasi antara petugas akuntansi dan petugas aset BMD, memotivasi SDM untuk mengikuti pelatihan perubahan sistem akuntansi dan mendorong untuk mengembangkan keahlian di bidang teknologi informasi, serta membantu manajemen dalam pengambilan keputusan dengan memantau langsung serapan anggaran melalui SIMRAL.

\subsection{Saran}

Untuk perlu adanya upaya akselerasi standar akuntansi pemerintahan berbasis akrual dengan peraturan lokal di Pemerintah Daerah maupun Provinsi. Untuk BPKAD Provinsi Sulawesi Utara selanjutnya agar lebih memperhatikan kesesuaian dalam penjelasan terutama untuk akun aset tak berwujud dalam Catatan Atas Laporan Keuangan (CALK). Untuk BPKAD Provinsi Sulawesi Utara agar menambahkan penyajian dan pengungkapan terutama untuk Laporan Operasional (LO) dan laporan perubahan ekuitas dalam Catatan Atas Laporan Keuangan (CALK). Untuk perlu adanya pengembangan atas pemahaman para pengelola keuangan mengenai SAP berbasis akrual, misalnya sosialisasi berupa seminar atau diskusi dengan aparat pemerintah, serta dilakukan pelatihan berkaitan dengan SAP berbasis akrual. 


\section{DAFTAR PUSTAKA}

Darise, N. (2008). Akuntansi keuangan daerah (Akuntansi sektor publik). Jakarta: PT Indeks.

Halim, A., \& Kusufi, M. S. (2014). Teori, konsep dan aplikasi akuntansi sektor publik, Edisi dua. Jakarta: Salemba Empat.

Lamonisi, S. (2016). Analisis penerapan standar akuntansi berbasis akrual pada Pemerintah Kota Tomohon. Jurnal EMBA: Jurnal Riset Ekonomi, Manajemen, Bisnis dan Akuntansi, $4(1)$,

223-230. https://ejournal.unsrat.ac.id/index.php/emba/article/view/11592.

Langelo, F., Saerang, D. P. E., \& Alexander, S. W. (2015). Analisis penerapan standar akuntansi pemerintahan berbasis akrual dalam penyajian laporan keuangan pada Pemerintah Kota Bitung. Jurnal EMBA: Jurnal Riset Ekonomi, Manajemen, Bisnis dan Akuntansi, 3(1), 1-8. https://ejournal.unsrat.ac.id/index.php/emba/article/view/6556

Mahsun, M. (2006). Pengukuran kinerja sektor publik. Yogyakarta: Badan Penerbitan Fakultas Ekonomi.

Permendagri Nomor 13 tahun 2006 tentang Pedoman Pengelolaan Keuangan Daerah.

Permendagri Nomor 64 tahun 2013 tentang Penerapan Standar Akuntansi Pemerintahan Berbasis Akrual pada Pemerintah Daerah.

Peraturan Pemerintah Nomor 24 Tahun 2005 tentang Standar Akuntansi Pemerintah.

Peraturan Pemerintah Nomor 71 Tahun 2010 tentang Standar Akuntansi Pemerintah.

Rombebunga, F., Saerang, D. P. E., \& Budiarso, N. S. (2018). Evaluasi penyajian laporan keuangan dinas pekerjaan umum Kota Bitung berdasarkan penerapan peraturan Pemerintah No 71 tahun 2010. Jurnal Riset Akuntansi Going Concern, 13 (4), 295301.

Sujarweni, V. W. (2014). Akuntansi biaya: Teori dan penerapannya. Yogyakarta: Pustaka Baru Press.

Sukamdaru, H., Subroto, B., \& Mardiati, E. (2017). Understanding factors affecting local administration reform on accrual based financial statements. Journal of Accounting and Business Education, 2(1), 54-77. http://dx.doi.org/10.26675/jabe.v1i1.9750.

Surepno. (2015). The key success and strategic role of accrual based accounting implementation. Journal The Winners, 16(2), 142-151. https://doi.org/10.21512/tw.v16i2.1567.

Tumbel, J., Pangemanan, S., \& Alexander, S. (2019). Penerapan sistem akuntansi keuangan daerah pada Badan Perencanaan Penelitian dan Pengembangan di Kabupaten Minahasa Selatan. Indonesia Accounting Journal, 1(2), 120-128. https://doi.org/10.32400/iaj.26815

Undang-Undang Republik Indonesia Nomor 32 tahun 2004 tentang Pemerintahan Daerah.

Undang-Undang Republik Indonesia Nomor 33 tahun 2004 tentang Perimbangan Keuangan antara Pemerintah Pusat dan Pemerintah Daerah.

Undang-Undang Republik Indonesia Nomor 1 tahun 2004 tentang Perbendaharaan Negara. 